\title{
Teacher Perception of National TVET Standard at Vocational High School in Indonesia
}

\author{
Aye Aye Mon \\ Mechanical Engineering Department \\ Technical Promotion Training Centre Myanmar \\ Baelin, Myanmar
}

\author{
Lilik Anifah \\ Informatics Department \\ Universitas Negeri Surabaya \\ Surabaya, Indonesia \\ lilikanifah@unesa.ac.id
}

\begin{abstract}
Vocational education is one solution to improve the quality of human resources in Indonesia. The challenge as well as the advantages for Indonesia is a large demographic area, so that the standardization of vocational education is needed. In this study, it is discussed how the perceptions of standard vocational education in Indonesia when it is viewed from the perspective of teachers. The method used is mix method, which combines both qualitative and quantitative methods. The respondents are teachers teaching in Vocational High School in Indonesia from East Java, West Java, Central Java, Jogjakarta, East Kalimantan, Riau Sumatera, South Kalimantan, and Madura Island. Numbers of respondents were 256 teachers consisting of 89 women and 167 men. The results showed that the status of development of national standard for TVET personnel revealing 152 respondents who stated that they have already developed the standard and 92 respondents who answered to be not developed, and 8 respondents answered for not sure. Indonesia has developed a standard of vocational education but it is still applied to all levels of either formal or non-formal vocational education including Vocational High School education, university, polytechnic and training.
\end{abstract}

Keywords—TVET, SKKNI, KKNI, Framework

\section{INTRODUCTION}

Indonesian education is still behind the international and ASEAN level in term of the quality [1]. Indonesia has a large area and has abundant natural resources. It is therefore, the development of human resources is very important to be improved. A wide area becomes a challenge for Indonesia to set education standards, so that in all parts of Indonesia would be getting better education with the same quality.

Vocational education is defined as a curriculum which requires the individual to understand and apply various levels of appropriate skill to be brought in the occupation-world. The science and mathematics requirement is more advanced than that required for a middle-type craft or skilled-trades occupation [2].

The challenges for TVET are its contribution to the development of a network for information and technology transfer, empowering the schools and strengthening the training curriculum and program development. Indonesia moves toward the era of economic globalization, the economy requires the TVET to provide the skills and knowledge for graduates to be a cadre of productive workforce.

Future development of TVET in Indonesia is anchored on 3 governmental pillars: (1) to improve the quality and relevancy of TVET; (2) to extend the access to vocational education; and, (3) to implement good governance in managing TVET schools. Pursuing these goals is necessary because the structural shift of the Indonesian economy has changed the characteristic of the labour force and the demand for science and work skills. This policy shift is affected by the manner by which TVET is managed. It requires an active involvement of industry in setting the standards, the development of the curriculum and in the overall management of the TVET system [3]

The qualification system in a country is solved by developing National Qualification Framework (NFQ) [4]. NFQ has gaining its popularity within 5 years, and more than 100 countries are now implementing, developing, or considering NFQ [5]. There has been some research about NFQ in some countries [6-9]. Indonesian National Qualifications Framework (NQF) is leveling learning outcomes frameworks for formal and non formal employment experience in various sectors [10]. Research on NQF has been widely discussed in some countries, but how TVET teachers' perceptions of the TVET education standard in Indonesia have never been discussed. This research is a part of TVET research personnel conducted by the researcher. This paper is limited to discuss how the TVET teachers' perception of vocational education standards in Indonesia is.

The purpose of this research is to investigate the status of development of national standard for TVET personnel and the status of implementation of national standard for TVET personnel based on teachers' perception. The main aim of this research is to investigate the data directly from TVET personnel which is expected to be one reflection of TVET teacher's understanding about TVET standard in Indonesia. 


\section{METHOD}

The method of this research is a mix method, which combines both qualitative and quantitative methods. The respondents are teachers teaching in Vocational High School in Indonesia. The method of research national standard for TVET personnel is shown in Fig 1. The researchers realize that Indonesia is so vast that this research takes representatives from several regions and provinces. Some representatives are teachers from East Java, West Java, Central Java, Jogjakarta, East Kalimantan, Riau Sumatera, South Kalimantan, and Madura Island.

The numbers of respondents were 256 teachers consisting of 89 women and 167 men. The Education backgrounds of the respondents consisting of 48 teachers who has postgraduate certificate, 206 of Bachelor Degree, 1 teacher of Diploma IV, and 1 teacher of Diploma III. Expertise of the teacher in Education consisting of 111 teachers, ICT as many as 27 teachers, Management as many as 7 teachers, Engineering as many as 115 teachers, Business and Administration as many as 15 teachers, and Mechanical as many as 3 teachers.

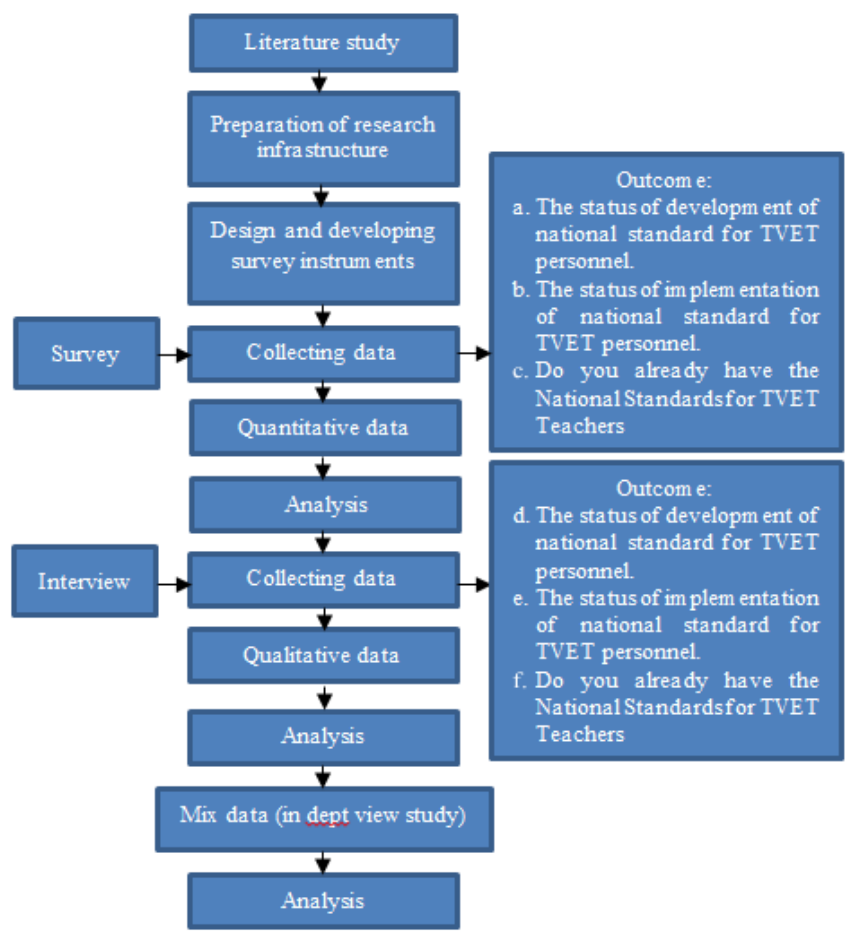

Fig 1. The method of research national standard for TVET personnel

\section{RESULT}

\section{A. Status of development of national standard for TVET personnel.}

The status of development of national standard for TVET personnel consisted of 152 respondents. They stated that they have already developed the standard and 92 respondents who answered haven't developed it, and 8 respondents who answered for not sure about it.

The status of development for school/college and principal/director standard of 232 respondents stated that they have already developed it and 20 respondents who answered haven't developed it, and 4 respondents who answered for not sure.

The status of development for trainer of trainers standard were 34 respondents who have already developed the standard and 46 respondents who answered have not developed it, and 176 respondents who answered for not sure.

The status of development for industry trainer standard were 61 respondents who answered to have already developed the standard and 14 respondents who answered have not developed it, and 181 respondents who answered for not sure. The status of development of national standard for TVET personnel is illustrated in figure 1.

\section{B. Status of implementation of national standard for TVET personnel}

The status of implementation of national standard for teacher standard were 154 respondents who have already developed the standard and 1 respondent who answered have not developed it, and 1 respondent who answered for not sure.

The status of implementation of national standard for School/college and Principal/Director standard were 229 respondents who have already developed the standard and 2 respondents who answered have not developed it and 1 respondent who answered for not sure.

The implementation of standard for trainer of trainers were 29 respondents who stated that they have already developed the standard and 2 respondents who answered have not developed it, and 3 respondents who answered for not sure. 


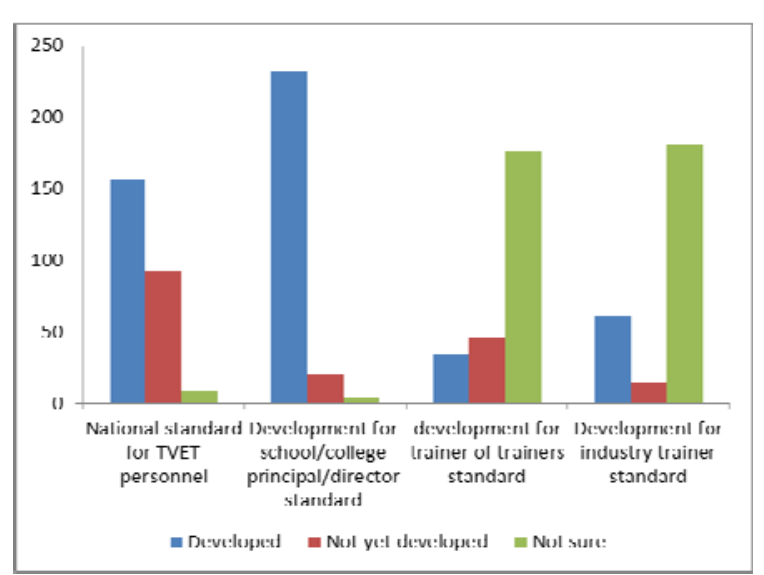

Fig 2. Status of development of national standard for TVET personnel

The implementation of industry for trainer standard state were 2 respondents who have already developed the standard and 6 respondents who answered have not developed it, and 3 respondents who answered for not sure. The status of implementation of national standard for TVET personnel is depicted in Fig 3.

\section{Had you already have the National Standards for TVET Teachers in your Country/Institution?}

The national Standards for TVET Teachers were 228 respondents who answered that they have already had the National Standards for TVET and 28 who answered that they don't have the National Standards for TVET Teachers.

The suggestions or recommendations in order to improve the development and dissemination process from respondents are socialized for teachers. It then must be increased. The government must increase in case of aiding for teacher training, education and training to the lowest level, and more workshop and curriculum development for vocational teachers.

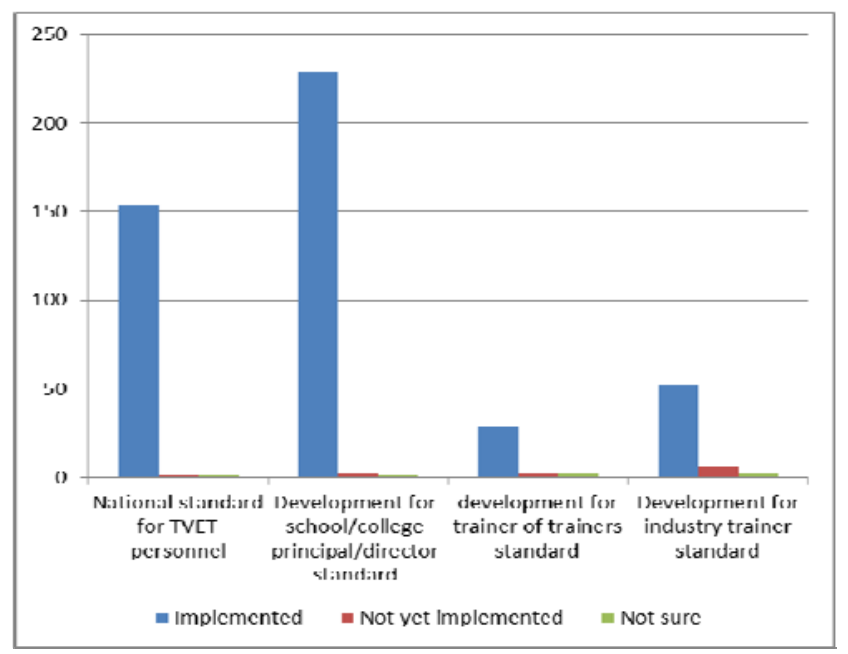

Fig 3. Status of implementation of national standard for TVET personnel

\section{DISCUSSION}

Based on the survey results of 156 respondents, it is said that TVET Standard have been developed, 92 respondents answered to have not developed it, and 8 respondents who answered for not sure. It is reasonable for those who answered to have been developed because:

- There is a document that states about KKNI (National Qualification Framework) from The Ministry of Education and Culture of Indonesia.

- The existence of socialization of Indonesian National Work Standards Competency or Standar Kompetensi Kerja Nasional Indonesia (SKKNI) from The Ministry of Labor.

- There are some levels of professional certification for professionals.

Indonesia has developed the Indonesian National Qualifications Framework. The Indonesian National Qualifications Framework holds a legal endorsement in the form of Presidential Decree No. 8/2012, and addresses 9 Year schooling from TVET and Higher Education. The stages of the NFQ's implementation are currently being designed [5].

The Ministry of Education and Culture has produced a key strategic document on the NQF (Directorate General of Higher Education, n.d.). According to the Minister of Higher Education, the NQF is 'one of the national standards in the education sector from which graduates, education and training institutions who are under the authority of the Ministry of Education and Culture could assess their learning outcomes or certificates' proficiency in connection to one of the relevant qualification levels specified in the IQF' (Directorate General of Higher Education, n.d, p. 3).

The Indonesian Government sees the legal endorsement of the NQF in the context of other laws and regulations; as an example of Law no. 13/2003 which is pertaining to manpower development, Government Regulation no. 31/2006 regarding to the National Job Training System, and Law no. 20/2003 which is concerning the National Education System. The NQF is also in line with the existing regulations endorsed by other ministries and authorized institutions, concerning to the manpower quality and development and the competence certification (Ministry of Education and Culture, 2013).

The NQF consists of 9 levels which are characterized by both learning outcomes and job-specific competences. Descriptors at each level specify the learning outcomes or competences that can be demonstrated by an individual at that level. Descriptors are divided into two categories: general and specific. The general descriptors cover personality, working attitude and ethics, and are applicable to every Indonesian citizen at every level. The specific descriptors describe the knowledge and skills mastered by the individual, and are applied in specific level. 
TABLE I ACADEMIC QUALIFICATIONS AND INDONESIAN IQF LEVEL

\begin{tabular}{|c|c|c|c|c|}
\hline Academic Qualifications & IQF & \multicolumn{2}{|c|}{$\begin{array}{c}\text { Technical and Vocational Education } \\
\text { and Training }\end{array}$} \\
\hline S\# & 9 & S3(Applied) & Specialist \\
\hline S2 & 8 & S2(Applied) & & \\
\hline & 7 & & & Profession \\
\hline S1 & 6 & D IV & & \\
\hline & 5 & D III & & \\
\hline & 4 & D II & & \\
\hline & 3 & D I & & \\
\hline General High School & 2 & \multicolumn{5}{|l|}{$\begin{array}{l}\text { Vocational High School } \\
\text { Junior High School }\end{array}$} & 1 & Junior High School & \\
\cline { 1 - 2 } & \multicolumn{5}{|l|}{}
\end{tabular}

Table 1 illustrates the referencing scheme between the learning outcomes of different education background and IQF qualification levels. This scheme will make it easier to ensure that graduates of educational programmes possess the right competences at the right level.

Indonesian National Work Standards Competency is issued by The Ministry of Labor. Indonesian National Work Standards Competency is developed based on the results of job analysis work done by the experts and experienced as well as competent sources. The analysis of labor competency can be formulated like in case of tasks, duties and steps for each job title. In the standards of performance of each task, the steps analyzed the competency requirements which include knowledge, skills, attitudes and behaviors as well as material that is already available.

When they are analyzed in the more detail, there is relationship between National Qualification Framework and Indonesian National Work Standards Competency. In Indonesian National Work Standards Competency, the methods of categorizing the level of work are also found in the educational level in National Qualification Framework. National Qualification Framework also appreciates for not only in the formal education, but it does also have the same level as the formal education which is also appreciated. It is characterized by the figure below:

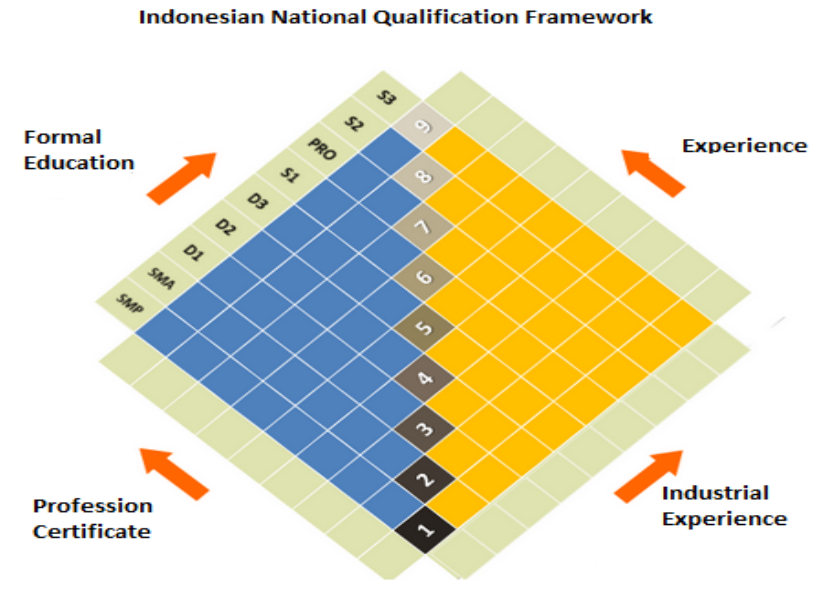

Fig 4. Indonesian National Qualification Framework
In the National Qualification Framework, the formal education, the professional certificate, the ability in the industrialized world (workplace) or the self-taught experience is also appreciated. It means that work experience, selflearning, as well as professional certificates can be converted in National Qualification Framework level.

It is implicitly legal that there is a link and match between formal education (Ministry of Education and Culture) and work needs in the field with their Indonesian National Work Standards Competency issued by the Ministry of Labor. The challenge is how to socialize and implement at the all levels of society, both in industry and in the world of education, and make it to be a synergy between industry and formal education.

Some of respondent (75 respondents) have answered that they have not developed the standard because there is no specific core standard developed for TVET personnel, there is also no existing National Qualification Framework developed for all levels of education, both in the formal education and vocational education. Although Indonesian National Work Standards Competency is developed for Indonesian National Standard Competence for worker, they are not for TVET Education.

\section{CONCLUSION}

Indonesia has developed a standard of vocational education that applies to all levels of formal and non-formal vocational education including vocational High School education, university, polytechnic and training. The NQF consists of 9 levels characterized by both learning outcomes and job-specific competences. Descriptors at each level specify the learning outcomes or competences that can be demonstrated by an individual at that level. The perceptions of TVET teachers who claim that they have the standard are because they considered the required standards for vocational education. Its implementation in vocational education is considered to some standards that they have been issued by the Ministry of Education and Culture, the Ministry of Labour, as well as standards which are issued by the National Standardization Institution. This effort has been done to graduates of vocational high school in order for them to be well received by their stakeholders and workplace where they work.

\section{REFERENCES}

[1] D Sulisworo, The Contribution of the Education System Quality to Improve the Nation's Competitiveness of Indonesia, Journal of Education and Learning (EduLearn) 2016, pp 127-138

[2] Halden A. Morris, Advancing Education through a Culture of Inquiry, Innovation and Indigenization April $23-25,2013$, St Augustine Campus, 2013.

[3] Nestor Reyes Balmores, International Approaches to TVET Development A Training Seminar for the Ministry of Education of Afghanistan Held 21-23 November 2005, UNESCO-UNEVOC International Centre for Technical and Vocational Education and Training, 2005. 
[4] Michael F.D. Young, National Qualifications Frameworks: An Analytical Overview, International Handbook of Education for the Changing World of Work, Springer, 2017.

[5] Stephanie M Allais, "The impact and implementation of national qualifications frameworks: a comparison of 16 countries", Journal of Education and Work, Taylor and Francis, Volume 24, 2011 - Issue 3-4, pp 233-258, June 2011.

[6] David Philips, "Lessons from New Zealand's National Qualifications Framework", Journal of Education and Work, Taylor and Francis, Volume 16, 2003 - Issue 3, pp 289-304, August 2010.

[7] David Raffe, National Qualifications Frameworks in Ireland and Scotland: A Comparative Analysis, presented at the European Conference on Educational Research, Vienna, 28-30 September 2009

[8] R Malherbe, S Berkhout, The national qualifications framework and the unconstitutional limitation of academic freedom, South African Journal of Higher Education Vol.15 No. 2, pp 62-73, 2001.

[9] Mari Elken, 'EU-on-demand': developing national qualifications frameworks in a multi-level context, European Educational Research Journal, Vol 15, Issue 6, 2016.

[10] Endang Komara, Indonesian National Framework (NQF) and The Autonomy of Nation, International Journal of Current Research, Vol. 8, Issue, 11, pp.42550-42553, November, 2016

[11] Directorate General of Higher Education (n.d.) Indonesian Qualifications Framework (Kerangka Kualifikasi Nasional Indonesia) Presidential Decree no. 8/2012: Implication and Implementation Strategies. Jakarta, Ministry of Education and Culture 